VOLUME 5

No. 2, 22 Juni 2016

Halaman 81-146

\title{
ANALISIS VEGF PADA PERGERAKAN GIGI ORTODONTI SETELAH PEMBERIAN SEDUHAN KOPI ROBUSTA ( COFFEACANEPHORA)
}

\author{
Herniyati \\ Fakultas Kedokteran Gigi Universitas Jember \\ Email: herniyati@unej.ac.id
}

\begin{abstract}
Background: Orthodontic tooth movement depends on bone remodeling. VEGF plays an important role in bone remodeling in both pressure area and tension area. Robusta coffee contains caffeine, chlorogenic acid and caffeic acid. Caffeine may increase osteoclastogenesis, and caffeic acid has antioxidant effects that may reduce oxidative stress in osteoblasts Objective: To analysis of VEGF of orthodontic tooth movement post robusta coffeesteeping administration. Material and methods: The experimental laboratories research used 16rats were divided into 2 groups. Group A: the rats were applied with orthodontic mechanical force (OMF) and group B: OMF + coffee steeping of 20mg /100 g of $B W$. OMF was conducted by applying ligature wire with a diameter of $0.20 \mathrm{~mm}$ on the molar-1 (M-1) and both incivus of right maxilla. Subsequently, M-1 of right maxilla was moved to mesial with Niti closed coil spring. Observations were made on days 15 and 22 by taking the gingival crevicular fluid by putting paper point on the gingival sulcus of mesio-and disto-palatal area of M-1 of right maxilla to determine the levels of VEGF using ELISA method. Results: the administration of Robusta coffee steeping increased the levels of VEGF in both compression area and tension area $(p<0.05)$. The levels of VEGF in tension area larger than the compression area $(p>0.05)$. Conclusion: the Robusta coffee steeping administration increased the levels of VEGF of orthodontic tooth movement, therefore it may improve alveolar bone remodeling process and it may be an alternative to accelerate orthodontic treatment.
\end{abstract}

Keywords: Bone remodeling; Gingival Crevicular Fluid; Orthodontic tooth movement; Robusta Coffee; VEGF.

\begin{abstract}
ABSTRAK
Pergerakan gigi ortodonti tergantung pada remodeling tulang. VEGF mempunyai peran penting pada remodeling tulang pada daerah tekanan dan tarikan dari ligamen periodontal. Kopi Robusta mengandung kafein yang dapat meningkatkan osteoklastogenesis dan Chlorogenic acid serta caffeic acid yang mempunyai efek antioksidan, dapat mengurangi stresoksidatif pada osteoblas. Tujuan: Untuk menganalisis VEGF pada pergerakan gigi ortodonti setelah pemberian seduhan kopi Robusta. Bahan dan Metode: Penelitian eksperimental laboratoris ini menggunakan 16 ekor tikus yang dibagi menjadi dua kelompok. Kelompok A: tikus diberi gaya mekanis ortodonti (GMO) dan kelompok B: GMO + seduhan kopi Robusta 20mg / $100 \mathrm{~g}$ BB. GMO dilakukan dengan memasang kawat dengan diameter $0.20 \mathrm{~mm}$ pada molar-1 (M-1) kanan dan kedua incisivus rahang atas (RA). Selanjutnya, M-1 RA kanan digerakkan ke mesial menggunakan Tension Gauce untuk menghasilkan kekuatan $10 \mathrm{~g} / \mathrm{cm} 2$ dengan $\mathrm{Ni}$-Ti orthodontic closed coil spring. Pengamatan dilakukan pada hari ke 15 dan ke 22 dengan mengambil gingival crevicular fluid dengan meletakkan paper point pada sulkus gingiva pada bagian mesio- dandisto-palatal M-1 RA kanan, kemudian ditentukan kadar VEGF dengan menggunakan metode ELISA. Hasil: pemberian seduhan kopi Robusta efektif meningkatkan kadar VEGF pada daerah tekanan dan daerah tarikan $(\mathrm{p}<0,05)$. Kadar VEGF pada daerah tarikan lebih besar daripada daerah tekanan $(p>0,05)$. Kesimpulan: pemberian seduhan kopi Robusta meningkatkan kadar VEGF pada pergerakan gigi ortodonti, sehingga dapat meningkatkan proses remodeling tulang alveolar dan dapat menjadi alternatif untuk mempercepat perawatan ortodonti.
\end{abstract}

Kata kunci: Gingival Crevicular Fluid; Kopi Robusta; Pergerakan gigi ortodonti; Remodeling tulang; VEGF. 


\section{PENGANTAR}

Pergerakan gigi ortodonti terjadi karena adanya rangsangan mekanik yang diikuti dengan remodeling tulang alveolar dan ligamen periodontal (PDL). Remodeling tulang adalah proses resorpsi tulang di daerah tekanan dan pembentukan tulang pada daerah tarikan. Pergerakan gigi ortodonti dapat dikontrol dengan besarnya gaya yang diterapkan dan respons biologis dari PDL (Miekle, 2006). Gaya yang diterapkan pada gigi akan menyebabkan perubahan dalam lingkungan mikro sekitar PDL karena perubahan aliran darah, yang mengarah ke sekresi mediator inflamasi seperti sitokin, faktor pertumbuhan, neurotransmiter, colony-stimulating-faktor, dan metabolit asam arakidonat. Sebagai hasil dari sekresi ini, terjadi renovasi tulang (Krishnan dkk., 2006).

Vascular Endothelial Growth Factor (VEGF) merupakan sistokin yang terlibat dalam Sing angiogenesis.Selama pergerakan gigiortodonti, kekuatan tekan menginduksi pembentukan pembuluh darah baru pada periodonsium dengan aktivasi VEGF. VEGF diketahui menjadi faktor angiogenesis diproduksi oleh berbagai jenis sel termasuk fibroblas, sel otot polos, kondrosit hipertrofi, osteoblas dan lain-lain. VEGF immunoreactivity ditemukan dalam sel endotel vaskular, dalam fibroblas yang berdekatan dengan jaringan hialinisasi, sebuah daerah nekrotik di daerah tekanan pada osteoblas, osteoklas, dan sel mononuklear (Miyagawa, 2009).

VEGF dapat memodulasi perekrutan, diferensiasi dan aktivasi prekursor osteoklas, sehingga meningkatkan resorpsi tulang. VEGF secara tidak langsung menyebabkan resorpsi tulang, karena mempromosikan angiogenesis secara in vitro, yang memungkinkan kapiler baru untuk membantu perekrutan osteoklas ke dekat permukaan tulang ke daerah resorpsi (Cheung dkk., 2011). VEGF dapat menginduksi neovaskularisasi. Hasil penelitian menunjukkan bahwa penerapan gaya mekanis untuk menggerakkan gigi secara eksperimental jumlah osteoklas meningkat karena VEGF. pada penelitian ini, VEGF terdeteksi pada osteoblas dan jaringan perio- dontal pada daerah tekanan dan daerah tarikan tulang alveolar (Kawata dkk., 2011). Pada hewan coba mRNA VEGF ditemukan pada fibroblas dan osteoblas di daerah tarikan ligamen periodontal tikus selama pergerakan gigi ortodonti eksperimental (Kaku dkk., 2008) yang merangsang angiogenesis, proses penting pada pembentukan tulang baru (Dai dkk., 2007).

Keberhasilan perawatan ortodonti dipengaruhi oleh sejumlah faktor, termasuk kesehatan periodontal, kebersihan mulut, dan kekuatan ortodonti. Pengembangan metode baru untuk mempercepat pergerakan gigi ortodonti telah dilakukan untuk mempercepat waktu perawatan, mengurangi efek samping seperti sakit, ketidaknyamanan, karies gigi, dan penyakit periodontal, dan meminimalkan kerusakan iatrogenik seperti resorpsi akar dan efek dari gigi nonvital (Arifin dkk., 2011). Upaya untuk mempercepat pergerakan gigi ortodonti telah dilakukan, antara lain dengan penggunaan obat-obatan (Shenava dkk., 2014). Kopi saat ini menjadi salah satu minuman paling populer di dunia yang dikonsumsi masyarakat. Kopi robusta mengandung kafein yang dapat meningkatkan pembentukan osteoklas melalui melalui COX-2/PGE2 dan peningkatan RANKL (Panggabean, 2011; Schipani E dkk., 2009).

Di samping itu, kopi juga mengandung chlorogenic acid dan caffeic acid yang mempunyai efek sebagai antioksidan, yang dapat mengurangi stres oksidatif pada osteoblas. Pengaruh seduhan kopi Robusta terhadap kadar VEGF khususnya dalam meningkatkan jumlah osteoklas dan osteoblas pada pergerakan gigi ortodonti masih belum jelas. Tujuan penelitian adalah untuk menganalisis peran VEGF pada Gingival Crevicular Fluid (GCF) pada pergerakan gigi ortodonti setelah pemberian seduhan kopi Robusta. GCF merupakan sumber penting dari biomarker yang berhubungan dengan keadaan kesehatan jaringan periodonsium, yang sangat berguna dalam memantau efektivitas perawatan ortodonti dan respon dari tulang alveolar terhadap kekuatan ortodonti (Lauritano dkk., 2014). 


\section{Metode}

Eksperimental laboratories ini menggunakan 16 ekor tikus (Spraque Dauwley) jantan usia 3-4 bulan dengan berat badan 250-300 gram. Tikus dibagi secara acak ke dalam dua kelompok yaitu kelompok kontrol (A): tikus diberikan gaya mekanis ortodonti (GMO) + $2 \mathrm{ml}$ aquades, dan kelompok perlakuan (B): diberikan GMO dan seduhan kopi kering sebesar 20mg/100g BB yang dilarutkan dalam $2 \mathrm{ml}$ aquades. GMO pada tikus dilakukan dengan memasang kawat ligatur dengan diameter 0,20 $\mathrm{mm}$ pada gigi molar-1 (M1) rahang atas (RA) kanan dan pada kedua gigi insivus RA. Kemudian M-1 RA kanan digerakkan ke mesial menggunakan Tension Gauce untuk menghasilkan kekuatan $10 \mathrm{~g} /$ $\mathrm{cm}^{2}$ dengan Nickel Titanium Orthodontic closed coil spring panjang $6 \mathrm{~mm}$ (Sella dkk., 2012). Pengamatan dilakukan pada hari ke 15 dan hari ke 22 dengan mengambil gingival crevicular fluid (GCF) dengan meletakkan paper point pada sulkus gingiva bagian mesio- dan disto-palatal M-1 RA kanan selama 30 detik kemudian dimasukkan dalam tabung eppendorf (zia dkk., 2013). Kadar VEGF ditentukan dengan menggunakan metode ELISA. Pemasangan Nickel Titanium Orthodontic closed coil spring dan pengambilan GCF pada tikus dapat dilihat pada Gambar 1 dan Gambar 2. Data dianalisis dengan menggunakan Student't-test, paired t-test, dan Wikcoxon signed ranks test dengan tingkat kepercayaan 95\% $(\alpha=0,05)$. Penelitian ini telah di uji kelaikan etik oleh Komisi Etik Fakultas Kedokteran Gigi Universitas Airlangga, nomor: 8/KKEPK.FKG/II/2015

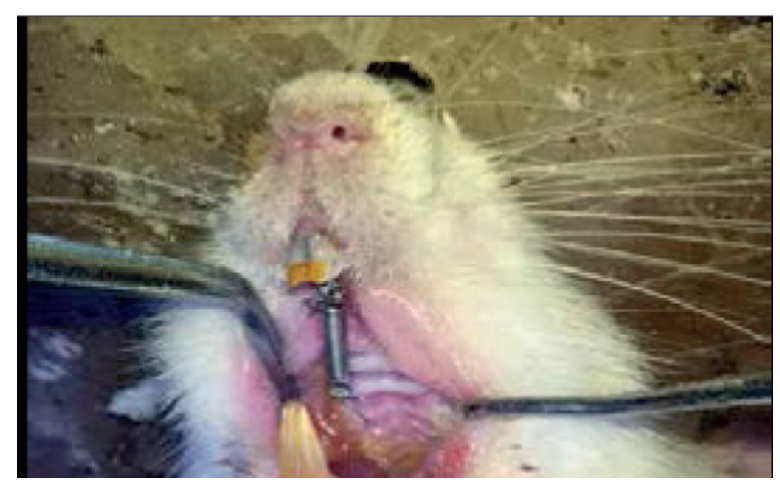

Gambar 1.

Pemasangan Nickel Titanium Orthodontic closed coil spring pada tikus

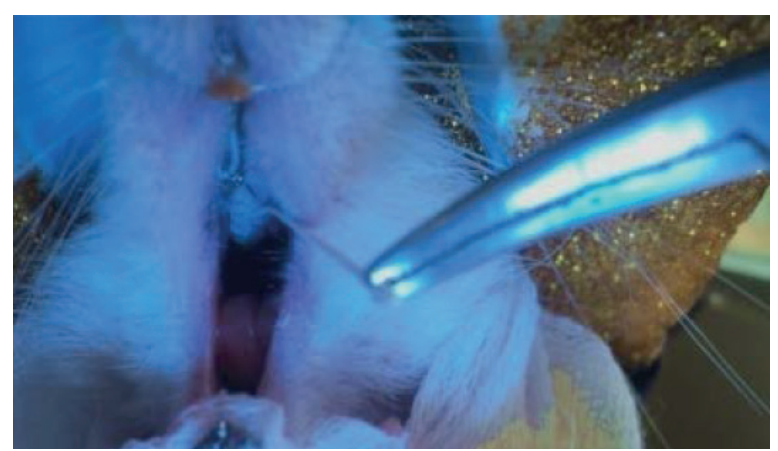

Gambar 2.

Pengambilan gingival crevicular fluid (GCF) pada sulkus gingiva bagian mesio- dan disto-palatal M-1 RA kanan tikus menggunakan paper point

\section{HASIL DAN PEMBAHASAN}

Hasil pengukuran kadar VEGF pada cairan sulkus gingiva di daerah tekanan dan tarikan antara kelompok A yang diberi GMO, dengan kelompok B yang diberi GMO + seduhan kopI pengamatan hari 15 dan hari 22 dapat dilihat pada Tabel 1.

Tabel 1

Rerata dan Simpang Baku Kadar VEGF dan Hasil Uji Beda Antarkelompok Penelitian pada Daerah Tekanan dan Daerah Tarikan

\begin{tabular}{lrrrcccc}
\hline & & \multicolumn{5}{c}{ VEGF $(\mathrm{pg} / \mathrm{ml})($ Rerata \pm Simpang baku) } \\
\cline { 3 - 7 } & \multirow{2}{*}{ Klp } & $\mathrm{n}$ & \multicolumn{3}{c}{ Hari ke-15 } & \multicolumn{3}{c}{ Hari ke-22 } \\
\cline { 3 - 7 } & & Tekanan & Tarikan & $\mathrm{p}$ & Tekanan & Tarikan & $\mathrm{p}$ \\
\hline A & 8 & $30,29 \pm 4,61$ & $42,16 \pm 8,68$ & $0,012^{*}$ & $28,38 \pm 6,88$ & $45,36 \pm 11,86$ & $0,036^{*}$ \\
\hline B & 8 & $78,45 \pm 3,16$ & $96,21 \pm 11,05$ & $0,060^{* *}$ & $93,91 \pm 19,05$ & $107,92 \pm 9,43$ & $0,207^{* *}$ \\
\hline p & & $0,000^{*}$ & $0,000^{*}$ & & $0,000^{*}$ & $0,000^{*}$ \\
\hline
\end{tabular}

* $\quad p<0.05=$ signifikan

** $\mathrm{p}>0.05=$ tidak signifikan 


\section{Kadar VEGF Pengamatan hari ke 15}

Tabel 1 menunjukkan rerata dan simpang baku kadar VEGF pada daerah tekanan pada hari ke 15 pada kelompok A dan kelompok B berturut-turut adalah $30,29 \pm 4,61 \mathrm{pg} / \mathrm{ml}$ dan $78,45 \pm 13,16 \mathrm{pg} / \mathrm{ml}$, sedangkan pada daerah tarikan pada kelompok A dan kelompok B berturut-turut $42,16 \pm 8,68 \mathrm{pg} / \mathrm{ml}$ dan 96,21 $\pm 11,05 \mathrm{pg} / \mathrm{ml}$. Hasil uji beda kadar VEGF antar kelompok penelitian pada daerah tekanan berdasarkan $t$ test dan pada daerah tarikan berdasarkan Wilcoxon Signed Ranks test menunjukkan kadar VEGF pada daerah tekanan maupun daerah tarikan pada kelompok kelompok B lebih besar daripada kelompok A $(p<0,05)$. Pengujian kadar VEGF antara daerah tekanan dengan daerah tarikan berdasarkan Wilcoxon Signed Ranks test pada kelompok A menunjukkan kadar VEGF pada daerah tarikan lebih besar daripada daerah tekanan $(\mathrm{p}<0,05)$, sedangkan pada kelompok B berdasarkan Paired t- test tidak signifikan $(\mathrm{p}>0,05)$

\section{Kadar VEGF Pengamatan hari ke 22}

Pada hari ke 22 pada daerah tekanan pada kelompok A dan kelompok B berturut- turut adalah $28,38 \pm 6,88 \mathrm{pg} / \mathrm{ml}$ dan $93,91 \pm$ $19,05 \mathrm{pg} / \mathrm{ml}$, sedangkan pada daerah tarikan pada kelompok A dan kelompok B berturutturut adalah 45,36 $\pm 11,86 \mathrm{pg} / \mathrm{ml}$ dan 107,92 $\pm 9,43 \mathrm{pg} / \mathrm{ml}$. Hasil uji beda antar kelompok penelitian pada hari ke 22 berdasarkan Wilcoxon Signed Ranks tes pada daerah tekanan dan berdasarkan t-test padadaerah tarikan menunjukkan kadar VEGF pada kelompok B lebih besar daripada pada kelompok A $(p<0,05)$. Pengujian kadar VEGF antara daerah tekanan dengan daerah tarikan berdasarkan Wilcoxon Signed Ranks test menunjukkan pada kelompok A kadar VEGF pada daerah tarikan lebih besar daripada daerah tekanan $(\mathrm{p}<0,05)$, sedangkan pada kelompok B tidak signifikan $(p>0,05)$.

\section{Perbandingan Antara Kadar VEGF Pengamatan Hari Ke 15 Dengan Hari Ke 22}

Kadar VEGF pada kelompok penelitian pada daerah tekanan dan daerah tarikan berdasarkan hari pengamatan ditunjukkan pada tabel 2 .

Tabel 2

Hasil Uji Beda Kadar VEGF Antara Hari Ke 15 Dengan Hari Ke 22 pada Masing-Masing Kelompok Penelitian pada Daerah Tekanan dan Daerah Tarikan

\begin{tabular}{|c|c|c|c|c|c|c|c|}
\hline \multirow{3}{*}{ Klp } & \multirow{3}{*}{$\mathbf{n}$} & \multicolumn{6}{|c|}{ VEGF (pg/ml) (Rerata \pm Simpang baku) } \\
\hline & & \multicolumn{3}{|c|}{ Tekanan } & \multicolumn{3}{|c|}{ Tarikan } \\
\hline & & Hari ke-15 & Hari ke-22 & $\mathrm{p}$ & Hari ke-15 & Hari ke-22 & $\mathrm{p}$ \\
\hline $\mathrm{A}$ & 8 & $30,29 \pm 4,61$ & $28,38 \pm 6,88$ & $0,401^{*}$ & $42,16 \pm 8,68$ & $45,36 \pm 11,86$ & $0,401^{*}$ \\
\hline B & 8 & $78,45 \pm 13,16$ & $93,91 \pm 19,05$ & $0,161^{*}$ & $96,21 \pm 11,05$ & $107,92 \pm 9,43$ & $0,059^{*}$ \\
\hline
\end{tabular}

* $p>0.05=$ tidak signifikan

Pada tabel 2 menggambarkan pengujian kadar VEGF berdasarkan hari pengamatan. Hasil uji berdasarkan Wilcoxon Signed Ranks test pada kelompok A menunjukkan pada daerah tekanan terdapat penurunan kadar VEGF hari ke 22 dibandingkan hari ke 15, tetapi tidak signifikan $(p>0,05)$. Sedangkan pada kelompok $\mathrm{B}$ menunjukkan terdapat peningkatan kadar VEGF hari ke 22 dibandingkan hari ke 15, tetapi tidak signifikan $(p>0,05)$. Pada daerah tarikan berdasarkan Wilcoxon Signed Ranks test pada kelompok A dan berdasarkan t-test pada kelompok B menunjukkan bahwa terdapat peningkatan kadar VEGF hari ke 22 dibandingkan hari ke 15 , tetapi tidak signifikan $(\mathrm{p}>, 05)$.

Pemberian kekuatan ortodonti pada gigi akan menghasilkan gerakan. Fenomena utama, baik sebelum dan setelah pergerakan gigi adalah remodeling tulang alveolar, 
peradangan jaringan, dan resorpsi akar. Ketika kekuatan ortodonti diaplikasikan pada gigi, daerah tekanan menunjukkan meningkatnya aktivitas osteoklastik, sedangkan pada daerah tarikan osteoblas mulai untuk berproliferasi dan terjadi mineralisasi matriks ekstraselular, keadaan ini menghasilkan remodeling tulang (Sprogar dkk., 2008).

Penerapan kekuatan ortodonti menyebabkan oklusi pembuluh darah secara alami menurunkan suplai darah, menyebabkan hipoksia di daerah tekanan. Hipoksia mempengaruhi tingkat energi sel dengan mengurangi aktivitas glikolitik dan produksi ATP. Sel-sel menanggapi hipoksia dengan mengekspresikan mediator seluler, terutama hypoxia-inducible factor 1 (HIF-1) yang dapat mempromosikan angiogenesis, merangsang proliferasi sel, dan mampu mencegah kematian sel. Hipoksia menginduksi pembentukan faktor transkripsi aktif HIF-1 dan mengaktifkan gen yang mengkode VEGF (Niklas dkk., 2013). Di samping itu, pergerakan gigi ortodonti menyebabkan aktivitas osteoblas meningkat, sehingga ekspresi VEGF juga mengalami peningkatan (D'Apuzzo dkk., 2013).

Pemberian seduhan kopi pada hari ke-15 maupun hari ke 22 meningkatkan kadar VEGF lebih besar pada daerah tekanan maupun pada daerah tarikan. Hal ini disebabkan karena kafein yang terkandung dalam kopi mempunyai efek dapat meningkatkan aktivitas osteoblas (Reis dkk.,2015), sehingga kadar VEGF juga meningkat. Selanjutnya VEGF akan menginduksi diferensiasi osteoklas yang berfungsi untuk resorpsi tulang (Andrade dkk., 2012). Penerapan gaya mekanis pada pergerakan gigi eksperimental menunjukkan jumlah osteoklas meningkat karena VEGF. Hasil penelitian sebelumnya juga menunjukkan bahwa kafein meningkatkan osteoklastogenesis melalui peningkatan RANKL, dan osteoklas yang aktif akan mengakibatkan resorpsi tulang (Meikle, 2006; Yamaguchi, 2009). Resorpsi tulang selanjutnya akan menyebabkan pergerakan gigi (Krishnan, 2006).

Peningkatan VEGF pada pemberian seduhan kopi juga disebabkan karena kandungan Chlorogenic acid dan caffeic acid yang terdapat dalam kopi. Menurut Kenisa Chlorogenic acid dan caffeic acid berperan sebagai antioksidan yang mempunyai efek meningkatkan angiogenesis melalui peningkatan VEGF (Kenisa. 2016). Di samping itu, Chlorogenic acid dan caffeic acid dapat mengurangi stres oksidatif pada osteoblas (Baek dkk., 2010), dapat meningkatkan osteoblastogenesis (Bin dkk., 2013),sehingga jumlah osteoblas meningkat dan VEGF juga mengalami peningkatan.

Osteoblas menghasilkan tulang melalui sintesis dan sekresi langsung kolagen tipe I, yang membuat lebih dari $90 \%$ dari protein matrik tulang. Ini, bersama-sama dengan beberapa jenis kecil kolagen, proteoglikan, fibronektin dan protein tulang tertentu, seperti osteopontin, sialoprotein tulang dan osteocalcin, menjadi osteoid fleksibel yang tidak termineralisasi. Mineralisasi dicapai dengan pelepasan lokal fosfat bersama-sama dengan kalsium yang terdapat pada cairan ekstraselular akan membentuk kristal hidroksiapatit [Ca10 (PO4) 6 (OH) 2] (Crockett dkk., 2011). Dengan demikian pemberian seduhan kopi dapat meningkatkan kadar VEGF, yang selanjutnya dapat meningkatkan jumlah osteoklas dan resorpsi tulang serta meningkatkan jumlah osteoblas dan pembentukan tulang sehingga dapat mempercepat proses remodeling tulang dan pergerakan gigi ortodonti.

Peningkatan kadar VEGF pada pemberian seduhan kopi masih terus terjadi pada hari ke 22 pada daerah tekanan dan daerah tarikan meskipun tidak signifikan, hal ini karena kekuatan ortodonti sudah mengalami penurunan meskipun proses remodeling tulang masih terus terjadi. Kadar VEGF pada daerah tarikan lebih besar daripada daerah tekanan, tetapi tidak signifikan, hal ini disebabkan daerah tarikan pembentukan tulang lebih banyak daripada daerah tekanan. Untuk itu, dapat disimpulkan bahwa seduhan kopi efektif meningkatkan kadar VEGF pada hari ke 15 pada daerah tekanan maupun daerah tarikan.

\section{SIMPULAN}

Hasil analisis data dan pembahasan dalam penelitian ini dapat disimpulkan bahwa 
pemberian seduhan kopi efektif meningkatkan kadar VEGF pada hari ke 15 pada daerah tekanan dan daerah tarikan. Selanjutnya terus terjadi peningkatan kadar VEGF pada hari ke 22, tetapi tidak signifikan. Dengan demikian seduhan kopi dapat dijadikan alternatif untuk mempercepat proses remodeling tulang dan pergerakan gigi ortodonti sehingga dapat mempercepat perawatan ortodonti.

\section{DAFTAR PUSTAKA}

Andrade JI, Taddei SRA, and Souza PEA. Inflammation and Tooth Movement: The Role of Cytokines, Chemokines, and Growth Factors. Seminar in Orthodontics. 2012; 18(4): 257-269

Ariffin SHZ, Yamamoto Z, Abidin IZZ, Wahab RMA, and Ariffin ZZ. Cellular and Molecular Changes in Orthodontic Tooth Movement. TheScientificWorldJournal. 2011; 11 Article ID 761768: 16 pages.

Baek KH, Oh KW, Lee WY, Lee SS, Kim MK, and Kwon HS. Association of oxidativestresswith postmenopausal osteoporosis and effects of hydrogen peroxide on osteoclast formation in human bone marrow cell cultures. Calcif Tissue Internat. 2010; 87 (3): 226-35.

Bin HS, Jeong JH, and Choi UK. Chlorogenic acid promotes osteoblastogenesis in human adipose tissue-derived mesenchymal stem cells.J.Food Sci Biotechnol. 2013; 22: 107-12.

Cardaropoli Dand Gaveglio L. The influence of orthodontic movement on periodontal tissues level. Seminars in Orthodontics. 2007; 13(4): 234-245.

Cheung WY, Liu C, Tonelli-Zasarsky RML, Simons CA, and You Lidan. Osteocyte apoptosis is mechanically regulated and induces angiogenesis in vitro. J Orthop Res. 2011; 29: 523530.

CrockettJC, Rogers MJ, Coxon FP, Hocking LJ, and Helfrich MH. Bone Remodelling at a Glance. J Cell Sci. 2011; 124: 991998.

Dai J, Rabie ABM. VEGF: An essential mediator of both angiogenesis and endochondral ossification. J Dent Res , 2007; 86:937-950.

D’Apuzzo F, Cappablanca S, Clavarella D, Monsurro A, Biavati A.S, and Perillo L. Biomarkers of Periodontal Tissue Remodelling during Orthodontic Tooth Movement in Mice and Men, Overview and Clinical Relevance, Scien.World J. 2013; 41: 342-53.

Jianru Y, Boxi Y, Meile L, Yu W, Wei Z, Yu L, and Zhihe Z. Caffeine may enhance orthodontic tooth movement through increasing osteoclastogenesis induced by periodontal ligament cells under compression. J.ArchOral Bio. 2016; 64: 51-60.

Kaku M, Motokawa M, Tohma Y, Tsuka N, Koseki $\mathrm{H}$, Sunagawa $\mathrm{H}$, Hernandes RAM, Ohtani J, Fujita T, Kawata $\mathrm{T}$, and Tanne K. VEGF and M-CSF levels in periodontal tissue during tooth movement. Biomedical Research. 2008; 29(4):181-187.

Kawata T, and Tanne K. Expression of vascular endothelial growth factor and the effects on bone remodeling during experimental tooth movement. Biomedical Research. 2011; 22 (2): 248-253 .

Kenisa PY, Istiati, and Setyari W. Effect of Robusta coffee beans ointment on full thickness wound healing. J.Dental Student. 2012; 45(1).

Krishnan V, Davidovitch Z. Cellular, Molecular and Tissue-Level Reaction to Orthodontics Force. Am J Orthod Dentofacial Orthop. 2006; 129: 1-32.

Lauritano D, Advantaggiato A, Cura F, Girardi A, and Carinci F. Biomarkers of periodontal tissue in gingival crevicular fluid during orthodontic movements: An overview. OA Dentistry. 2014; 18. 2(1): 1. 
Liu SH, Chen C, Yang RS, Yuan PY, Yang YT, and Tsai C. Caffeine enhances osteoclast differentiation from bone marrow hematopoietic cells and reduces bone mineral density in growing rats. Journal of Orthopaedic Research.2011; 29(6): 954-960.

Miyagawa A, Chiba M, Hayashi H, and Igarashi K. Compressive force induces VEGF production in periodontal tissues. Journal of Dental Research. 2009; 88 (8): 752-756.

Meikle CM. The tissue, cellular, and molecular regulation of orthodontic tooth movement: 100 years after Carl Sandstedt. Eur J Orthod. 2006; 28: 221-40.

Niklas A, Proff P, Gosau M., and Römer P. The Role of Hypoxia in Orthodontic Tooth Movement, International Journal of Dentistry. 2013; Article ID 841840: 7 pages.

Panggabean E. Buku pintar kopi . Jakarta: Agromedia Pustaka. 2011.h 5,124

Reis AS, Riberio LGR, Ocarino NM, Goes AlM, and Serakides $R$, . Osteogenic potential of osteoblasts from neonatal rats born to mothers treated with caffeine throughout pregnancy. BMD Musculoskeletal Disorder. 2015; 16: 10.

SchipaniE, MaesC, Carmeliet G, and Semenza GL. Regulation of OsteogenesisAngiogenesis Coupling by HIFs and
VEGF. J Bone Miner Res. 2009; 24(8): 1347-1353.

Shenava Shailesh, Nayak Krishna US, Bhaskar Vivek, Nayak Arjun. Accelerated Orthodontics-A Review. Internat J Scien Study.2014;1(5): 35-39.

Sella RC, de Mendonça MR., Osmar Aparecido Cuoghi OA, Li AnT. Histomorphic Evaulation of Periodontal Compresion and Tensien sides During Orthodontic Tooth Movement in Rats. J Orthod. 2012; 17(3): 108-17.

Sprogar S, Vaupotic T, Cör A, Drevenšek M, and Drevenšek G. The endothelin system mediates bone modeling in the late stage of orthodontic tooth movement in rats. Bone. 2008; 43(4): 740-747.

Zia A, S Khan, A Bey, ND Gupta, S MukhtarUn-Nisar. Oral biomarkers in the diagnosis and progression of periodontal diseases. Biology and Medicine. 2011; 3(2) Spesial Issue: 45-52.

Yashin A, Yashin Y, Wang JY, and Nemzer Bs. Antio- xidant and Antiradical Activity of Coffee, Antioxidants.2013;2: 230- 45.

Yamaguchi M. RANK/ RANKL/OPG During Orthodontic Tooth Movement. Orthod Craniofal Res. 2009; 12: 113-119. 